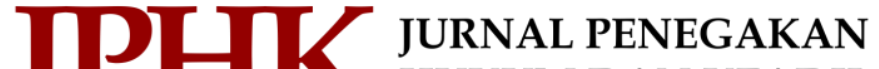 HUKUM DAN KEADILAN}

Vol. 1 No.1, Maret 2020
Gedung Pascasarjana Kampus Terpadu UMY Jalan Brawijaya, Tamantirto, Kasihan, Bantul, Yogyakarta 55183

Telepon: (0274) 387656 Ext. 346

Email : jphk@umy.ac.id

\title{
Problematika Hukum Formil Penyelesaian Sengketa Ekonomi Syariah Di \\ Pengadilan Agama \\ Sinta Noer Hudawati
}

Magister Hukum, Universitas Muhammadiyah Yogyakarta, E-mail: nurhudawari@gmail.com

\section{INFO ARTIKEL}

\author{
Perjalanan Artikel: Artikel \\ Dikirimkan oleh penulis: \\ 06-11-19 \\ Artikel Direview: 19-02-20 \\ Artikel Direvisi: 19-02-20 \\ Artikel Diterima atau \\ Dipublikasikan: 04-03-20
}

DOI: $10.18196 / j p h k .1102$

\section{Pendahuluan}

Pemikiran penelitian ini didasarkan atas kompleksitasnya permasalahan sengketa ekonomi syariah, yang terjadi dewasa ini. Pesatnya perkembangan ekonomi syariah berbanding lurus dengan banyaknya sengketa ekonomi syariah yang ada. Sengketa ekonomi syariah dalam penyelesaianya menjadi kewenangan Pengadilan Agama sejak adanya Putusan Mahkamah Agung Nomor 93/PUU-X/2012. Kewenangan tersebut merupakan kewenangan yang baru sehingga instrumen dalam penyelesaian sengketa ekonomi syariah juga harus di persiapkan, instrumen baru tersebut adalah sarana prasarana lembaga peradilan agama, meningkatkan kemampuan teknis sumber daya 
manusia, bekerja sama dengan perguruan tinggi, membentuk hukum formal dan materiil agar menjadi pedoman bagi aparat peradilan agama dalam memeriksa, mengadili dan memutus sengketa ekonomi syariah dan yang terakhir membenahi sistem dan prosedur agar sengketa yang menyakut ekonomi syariah dilaksanakan secara sederhana, mudah dan biaya ringan. ${ }^{1}$ Bahwa penyelesaian sengketa yang dilaksanakan di Pengadilan Agama yang menjadi permasalahanya aturan hukum formal dan materil masih mengadopsi hukum perdata yang kita ketahui hukum perdata landasan dasar yang digunakan adalah hukum barat atau hukum Belanda. Bahwa terkait hal tersebut banyak aturan hukum yang di pakai dalam penyelesaian sengketa ekonomi syariah masih mengacu pada hukum perdata yang kadang dalam pelaksanaannya jika diterapkan justru bertetangngan dengan pringsip syariah.Bahwa kenyataan dilapangan yang masih dalam tahap penataan dan pembuatan aturan hukum formil dalam penyelesaian sengketa ekonomi syariah agar bisa memenuhi apa yang menjadi amanat Undang-Undang Nomor 3 Tahun 2006, berlandaskan nilai-nilai syariah, itu menjadi probelm tersendiri dalam penyelesaian sengketa ekonomi syariah

Dalam penelitian ini menfokuskan terkait pembentukan hukum formal terkait sengketa ekonomi syariah, sejak di undangkan Undang-Undang Nomor 3 Tahun 2006 diperbarui dengan Undang-Undang Nomor 50 tahun 2009 tetang Pengadilan Agama, Pasal 49 huruf (i) yang memberi kewenangan Pengadilan Agama menjalankan sengketa ekonomi syariah sejak tahun 2006 sampai tahun 2016 dalam kurung waktu tersebut belum adanya hukum formil yang mengatur khusus tentang ekonomi syariah di Indonesia dan perkembanganya dalam proses pembentukan hukum materiil. Sehingga dalam penyelesaian sengketa ekonomi syariah masih menggunakan hukum acara perdata, hal tersebut sangat menarik bagi penulis untuk meneliti terkait Tata cara Pengadilan Agama dalam penyelesaian sengketa ekonomi syariah (Problematika hukum formil dalam ranah sengketa ekonomi syariah).

\section{Metode}

Penelitian hukum normatif ini menggunakan metode pendekatan perundangundangan (Statue Aproach) dan pendekatan konsep (Conceptual Aproach). Penelitian dilakukan dengan menemukan peraturan perundang-undangan sebagai dasar pijakan untuk menganalisis dan mencari konsep-konsep dalam ilmu hukum berupa asas, doktrin-doktrin sumber hukum dalamarti filosofis yuridis sebagai sudut pandang kajian yuridis terhadap kewenangan Pengadilan agama dalam penyelesaian sengketa ekonomi syariah. Bahan hukum yang dipergunakan ada 3 yaitu bahan hukum primer, bahan hukum sekunder berupa kajian teoritis yang berupa pendapat hukum, ajaran dan teori hukum sebagai bahan penunjang hukum primer; dan bahan hukum tersier atau bahan non hukum yaitu bahan hukum penelitian yang digunakan dalam penelitian untuk menjelaskan bahan hukum primer dan bahan hukum sekunder. Teknik Pengumpulan bahan hukum dilakukan dengan studi pustaka. Fakta empiris

\footnotetext{
${ }^{1}$ Majalah Peradilan Agama, 2015, Perumusan KHES, Edisi 8 Desember 2015, hlm. 6
} 
dalam penelitian ini dikumpulkn dengan penelitian lapangan, dengan mengambil lokasi penelitian di Pengadilan Agama Bantul. Analisis bahan-bahan penelitian tersebut, pertama-tama dilakukan dengan cara mengidentifikasi fakta hukum dan mengeleminasi hal-hal yang tidak relevan. Dilanjutkan dengan mengumpulkan bahanbahan hukum dan bahan non hukum yang relevan dengan isi hukum, serta menelaah isu hukum berdasarkan bahan yang telah di kumpulkan. Kesimpulan ditarik dalam bentuk argumentasi sesuai isu hukum.

\section{Analisis dan Hasil}

3.1. Penyelesaian Sengketa Ekonomi Syariah di Pengadilan Agama antara Tahun $2006-2016$

Penyelesaian sengketa ekonomi Syariah dalam kurun waktu 2006 sampai 2016, berdasarkan dari hasil penelitian menunjukkan fakta bahwa hukum formal yang dipergunakan adalah hukum acara perdata. Penggunaan hukum acara perdata dalam penyelesaian sengketa ekonomi Syariah didasarkan pada ketentuan undang-undang Pasal 54 Undang-Undang Nomor 7 Tahun 1989 junto Undang-Undang nomor 3 tahun 2006 tentang Perubahan Atas Undang-Undang Nomor 7 Tahun 1989 Tentang Peradilan Agama, yang menyatakan bahwa: "hukum acara yang berlaku pada pengadilan agama adalah hukum acara perdata yang berlaku pada pengadilan dalam lingkungan peradilan umum, kecuali yang telah diatur secara khusus dalam Undang-Undang ini". Hukum acara perdata tersebut sebagaimana yang berlaku di lingkungan peradilan umum, yakni hukum acara perdata sebagaimana diatur oleh HIR (Het Herzeine Inland Buitenggewesten) termasuk ketentuan yang diatur dalam Rv (Reglement of de Rechtsvordering), KUH Perdata, Undang-Undang Nomor 48 tahun 2009 tentang Kekuasaan Kehakiman, Undang-Undang Nomor 3 tahun 2009 tentang Mahkamah Agung dan UndangUndang Nomor 49 tahun 2009 tentang Peradilan Umum dan peraturan lain yang berkaitan ${ }^{2}$.

Hukum acara dipergunakan dalam penyelesaian sengketa ekonomi Syariah disebabkan oleh belum adanya hukum formal yang mengatur secara khusus tentang ekonomi syariah, hukum acara perdata yang digunakan sebagai acuan dalam penyelesaian penyelesaian sengketa ekonomi syariah ${ }^{3}$. Dengan demikian hukum formil yang digunakan untuk menyelesaikan sengketa ekonomi syariah dalam kurun waktu antara tahun 2006 sampai dengan tahun 2016 menggunakan hukum acara perdata yang bersumber dari HIR, RBG dan BW4. Hukum acara perdata tersebut belum secara jelas memuat nilai-nilai syariah yang diamanatkan dalam Undang-Undang Nomor 3 tahun 2006 tentang Perubahan Atas Undang-Undang Nomor 7 Tahun 1989 Tentang Peradilan Agama, diperbarui dengan Undang-Undang Nomor 50 tahun 2009 Tentang Perubahan Kedua

\footnotetext{
2 Amran Saudy, 2017, Penyelesaian Sengketa Ekonomi Syariah (Teori dan Praktek), Kencana, hlm. 25.

3 Ibid., hlm.77

4 Ibid., hlm. 6-9
} 
Atas Undang-Undang Nomor 7 Tahun 1989 Tentang Peradilan Agama yang menyatakan bahwa sengketa ekonomi syariah harus diselesaikan dengan berdasarkan prinsip-prinsip Syariah.

Ketidakjelasan penerapan nilai-nilai Syariah dalam hukum acara perdata yang digunakan untuk menyelesaikan sengketa ekonomi syariah tersebut penulis dapatkan dari hasil penelitian dengan membandingkan hukum acara perdata dengan nilai-nilai syariah yang terdapat dalam Al Quran dan Hadis. Sebelum membandingkan antara hukum acara perdata dengan kaidah nilai-nilai Syariah penulis akan menguraikan prosedur hukum acara perdata dalam proses penyelesaian sengketa ekonomi syariah sebagai berikut. Tahapan pemeriksaan sengketa ekonomi syariah dengan acara biasa sebagaimana diatur dalam hukum acara perdata 5 :

a. Tahap Pendaftaran Perkara

I. Pihak yang berperkara datang ke Pengadilan Agama dengan membawa surat Gugatan.

II. Pihak yang berperkara menghadap petugas meja pertama dan menyerahkan surat gugatan, minimal 6 rangkap.

III. Petugas meja pertama (dapat) memberikan penjelasan yang dianggap perlu terkait perkara yang diajukan, dan menaksir panjer biaya perkara yang kemudian ditulias dalam surat kuasa untuk membayar atau SKUM. besarnya panjer biaya perkara diatur dalam Pasal 193 R.Bg/Pasal 182 ayat (1) HIR/Pasal 90 ayat (1) UU-PA. biya tersebut digunakan untuk:

- pembiyayaan kepanitraan dan metrai

- biaya pemeriksan, saksi ahli, juru bahasa dan biaya sumpah

- biaya untuk pemeriksaan setempat dan perbuatan hakim yang lain jika ada

- untuk membayar biaya pemanggilan, pemberitahuan dan biayabiaya lain berkenaan dengan perkara ini. ${ }^{6}$

jika biaya tersebut kurang pihak yang berperkara bisa dimintai biaya lagi akan tetapi bila biaya tersebut masih akan dikembalikan kepada yang bersangkutan setelah perkara selesai disidangkan.

IV. Pihak berperkara membayar SKUM ke bank yang telah ditunjuk oleh Pengadilan Agama yang besarnya sesuai yang tertera dalam SKUM.

V. Blangko Skum kemudian dikembalikan ke kasir, kasir menandatangani surat kuasa untuk membayar, dan membubuhkan nomor urut perkara dan tanggal penerimaan perkara dalam SKUM yang telah di bumui cap luasdan surat gugatan kepada pihak yang berperkara.

5 Ibid., hlm.125

${ }^{6}$ Ibid., hlm. 59. 
b. Tahap Penangan Perkara di Persidangan

Perkara yang sudah di daftarakan pada Pengadilan Agama, oleh Penggugat.Pihak yang berkara maka langka selajutnya tinggal menunggu pangilan sidang dari juru sita/atau juru sita pengganti. Panggilan sidang harus sampai kepada para pihak sekurang-kurangnya 3 hari sebelum sidang. panggilan dilaksanakan di alamat para pihak, jika tidak diketumukan maka panggila disampaikan melalui Kepala Desa/Lurah dimana para pihak bertempat tinggal. Terkait tata cara pemanggilan sidang diatur dalam Pasal 390 jo Pasal 389 dan 122 HIR.Panggilan harus dilaksanakan secara resmi dan patut. ${ }^{7}$

c. Tahapan-tahapan Penangan Perkara Di Persidangan:

Upaya Perdamaian, dalam perkara perdata biasanya sebelum dimulai sidang hakim wajib menawarkan untuk mengupayakan adanya perdamaian atar para pihak yang berperkara, dalam hukum acara perdata perdamian diatur dalam Pasal 130 HIR/Pasal 154 R.Bg dan Pasal 14 ayat (2) UU No.14 tahun 19708 jika upaya perdamaian tidak bisa maka langka selajutnya hakim akan mengarakan para pihak untuk menempuh jalur mediasi sebagai mana yang diatur dalam PERMA No 1 Tahun 2016 tata cara mediasi khusus perkara sengketa ekonmi syariah", jika dalam tahap mediasi tersebut disepakati perdamaian maka akan dibuatkan akta perdamaian dan akata perdamaian ini mempunyai kekuatan hukum sama denga putusan hakim dan tidak bisa dimintakan Banding, kasasi dan Peninjauan Kembali, jika tidak ada upaya perdamaian maka perkara di lanjutkan. dalam setiap permulaan sidang yang membedahkan dengan sidangsidang di Pengadilan Negeri dengan pengadilan Agama yaitu Hakim membuka sidang di awali dengan ucapan Bissmillahirohmannirohkim baru dibuka dengan kalimat "Umum Demi Ketuhanan Yang Maha Esa sidang dibuka untuk umum" bahwa itu adalah penyimpangan atau penerapan Peraturan Khusus pada Pengadilan Agama yang diatur dalam Peraturan Mahkamah Agung Nomor 14 Tahun 2016 Tentang Tata Cara Penyelesean Sengketa Ekonomi Syariah. ${ }^{10}$.

d. Pembacaan Surat Gugatan

Bahwa hakim mempersilahakan pihak penggugat untuk membacakan surat gugatan, dan jika dalam gugatan tersebut tidak ada perubahan, revisi atau pencabutan, maka langka selanjutanya pihak hakim akan memberikan kesempatan pihak lawan untuk mengajukan jawaban, sidang di tundan.

e. Jawaban Tergugat

Setelah pihak Penggugat membacakan gugatan pihak lawan diberi kesempatan mengajukan jawaban, bisa lesan bisa tertulis hal tersebut diatur (Pasal 158 ayat

\footnotetext{
${ }^{7}$ Mukti Arto, 1996, Praktek Perkara Perdata Pada Pengadilan Agama,Yogyakarta, Pustaka Pelajar, hlm. 63.

8 Ibid., hlm. 95.

9 Amran Saudy, op. cit., hlm. 127.

10 Ibid., hlm. 127
} 
(1) R.Bg). Dalam tahap jawaban pihal Tergugat bisa mengajukan eksepsi, atau gugatan rekopensi tanpa perlu membayar biaya perkara. ${ }^{11}$

f. Tahap Replil Penggugat

Setelah tahapan Jawaban pihak Penggugat diberi kesempat untuk mengajukan bantahan atas jawaban Tergugat atau bisa juga membenarkan jawaban Tergugat atau tetap pada gugatanya.

g. Tahap Duplik

Setelah penggugat menyampaikan repliknya maka Penggugat diberi kesempatan mengajukan Duplik, bahwa jawab jinawab ini bisa berlangsung lebih dari satu kali, jika sudah dianggap cukup maka acara selanjutnya adalah Pembuktian.

h. Pembuktian

Tahap Pembuktian dalam sengketa ekonomi mengacu pada tahap pembuktian yang diatur dalam acara perdata yaitu dimana Penggugat di bebani kewajiban untuk membuktikan dalil-dali yang di sampaikan dalam gugatannya dan sebaliknya Tergugat juga dibani untuk membuktikan dalil bantahannya sebagaimana yang diatur dalam Pasal 163HIR/283 RBg.

i. Kesimpulan Para Pihak

Bahwa pada acara ini setelah kedua belah pihak mengjukan pembuktian baik tertulis dan saksi maka tahapan selanjutnya adalah Para Pihak diberi kesempatan untuk mengajukan kesimpulan hasil dari pemeriksaan sidang selama perkara berlangsung kepada majelis hakim.

j. Tahap Musyawarah Majelis Hakim

Rapat musyawarah hakim tersebut dilaksanakan secara tertutup dan bersifat rahasia sebagaimana diatur dalam Pasal 19 ayat (3) Undang-Undang No. 4 Tahun 2004 bahwa dalam rapat tersebut semua hakim menyampaikan pendapatnya baik lesan dan tertulis, jika terjadi perbedaan pendaat maka diambil suara terbanyak, dan pendapat yang berbeda tersebut dapat di muat dalam putusan (dissenting oponion).

k. Putusan Hakim

Setelah hakim selesai musyawarah dan telah menghasilkan putusan, maka hakim sesuai yang dijadwalkan akan membacakan putusan. Setelah di bacakan putusan tersebut bagi pihak yang tidak puas dengan putusan hakim bisa megajukan upaya hukum dalam tenggang waktu 14 hari setelah putusan di ucapakan. apabila salah satu pihak tidak hadir, maka juru sita akan memnyampaikan isi putusan atau putusan tersebut kepada pihak yang tidak hadir, dan jika pihak yang tidak hadir tidak puas dengan putusan hakim bisa mengajukan upaya hukum banding dalam kurung waktu 14 hari setelah putusan di terima yang bersangkutan.

11 Mukti Arto, op. cit., hlm.100 
Penyelesaian sengketa ekonomi syariah dengan menggunakan hukum acara perdata sepintas tidak ada bedanya dengan prosedur beracara pada pengadilan umum, bahwa dalam penelitian ini penulis melakukan penelusuran terkait proses beracara dengan hukum acara perdata/HIR dengan kaidah-kaidah syariah yang terdapat dalam Al-quran dan Hadist. Pembahasan harus dikemas secara runtut, logis, dan terfokus, yang di dalamnya terkandung pandangan orisinal dari penulisnya. Bagian pembahasan ini harus menyita porsi terbesar dari keseluruhan substansi tulisan.

Tabel 1. Tahapan Persidangan

\begin{tabular}{|c|c|c|c|c|}
\hline No & Tahapan & $\begin{array}{c}\text { Hukum Acara } \\
\text { Perdata }\end{array}$ & Kaidah Islam & Keterangan \\
\hline 1. & $\begin{array}{l}\text { Tahap proses } \\
\text { pendaftaran } \\
\text { perkara, } \\
\text { pengajuan } \\
\text { Gugatan }\end{array}$ & $\begin{array}{l}\text { Dalam hal tersebut } \\
\text { diatur dalam Pasal } \\
143 \text { B.Rg/Pasal } 119 \\
\text { HIR }^{12}\end{array}$ & $\begin{array}{l}\text { Dalam kaidah Islam } \\
\text { Hal tersebut tersirat } \\
\text { dalam Qs An-Nisa(4) } \\
\text { danAl-Maidah (49) }\end{array}$ & $\begin{array}{l}\text { Ada ketidak } \\
\text { samaan }\end{array}$ \\
\hline 2. & $\begin{array}{l}\text { Terkait dengan } \\
\text { Hakim }\end{array}$ & $\begin{array}{lr}\text { Kreteria } & \text { hakim } \\
\text { diatur } & \text { dalam } \\
\text { Peraturan } & \\
\text { Mahkamah } & \text { Agung. }\end{array}$ & $\begin{array}{l}\text { Dalam Hukum Islam } \\
\text { juga diatur terkait } \\
\text { kedudukan Hakim } \\
\text { dan Kreteria hakim } \\
\text { Qs.Al Nisa:34 dan } \\
\text { Hadis Al-Bukhori13 }\end{array}$ & $\begin{array}{l}\text { Ada } \\
\text { kesamaan }\end{array}$ \\
\hline 3 & $\begin{array}{l}\text { Tahap } \\
\text { Pembuktian }\end{array}$ & $\begin{array}{l}\text { Dalam HIR terkait } \\
\text { pembuktian yaitu } \\
\text { Alat bukti diatur } \\
\text { dalam Pasal } 164 \\
\text { HIR,14 }\end{array}$ & 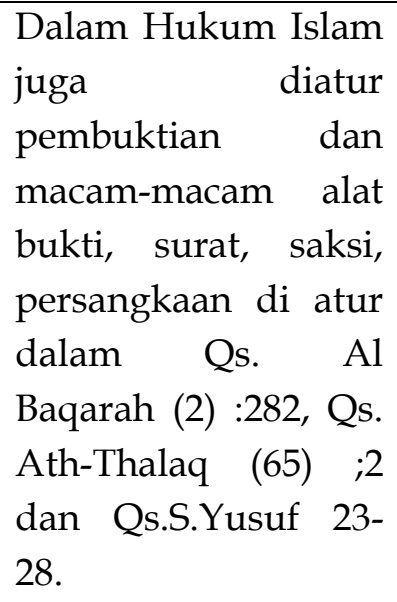 & $\begin{array}{l}\text { Dalam } \\
\text { pembuktian } \\
\text { dalam } \\
\text { hukum acara } \\
\text { perdata } \\
\text { dengan } \\
\text { kaidah- } \\
\text { kaidah Islam } \\
\text { tidak sama }\end{array}$ \\
\hline
\end{tabular}

\footnotetext{
12 Ibid., hlm. 41

13 Ibid.

14 Ibid., hlm.145
} 


\begin{tabular}{|l|l|l|l|l|}
\hline 4 & $\begin{array}{l}\text { Tahapan } \\
\text { pengambilan } \\
\text { keputusan }\end{array}$ & $\begin{array}{l}\text { Bahwa dalam } \\
\text { Pengambilan } \\
\text { keputusan hakim } \\
\text { diwajibkan } \\
\text { menggali segala hal } \\
\text { alasan hukum yang } \\
\text { tidak dikemukakan } \\
\text { oleh kedua belah } \\
\text { pihak Pasal 178 ayat } \\
\text { ayat yang mengatur } \\
\text { kedudukan hakim } \\
\text { dalam memutus } \\
\text { perkara, dalam hal } \\
\text { ini ada kadis yang } \\
\text { diriwayatkan Amer } \\
\text { Bin Ashar. }\end{array}$ & $\begin{array}{l}\text { Ketidaksama } \\
\text { an }\end{array}$ \\
\hline 5 & $\begin{array}{l}\text { Wanprestasi dan } \\
\text { Perbuatan } \\
\text { Melawan Huku }\end{array}$ & $\begin{array}{l}\text { Diatur dalam Pasal } \\
\text { 1244, Pasal 1245 dan } \\
\text { Pasal 1246 KUH } \\
\text { Perdata }\end{array}$ & $\begin{array}{l}\text { Diatur dalam ayat al- } \\
\text { Baqarah ayat 288 }\end{array}$ & $\begin{array}{l}\text { Ada ketidak } \\
\text { sesuaian }\end{array}$ \\
\hline
\end{tabular}

Berdasarkan bagan penelusuran hukum acara perdata (HIR dan $\mathrm{Rv}$ ) dengan kaidah Islam tersebut diatas terdapat persamaan dan perbedaanya. Bahwa kedua hukum tersebut sama-sama mengatur tetang berperkara melalui tahap pengadilan baik HIR dan kaidah Islam, dalam arti kedua hukum tersebut telah mengatur proses penyelesaian sengketa melalui pengadilan. Hukum Acara Perdata pada Pengadilan dalam HIR dan Pengadilan dalam hukum Islam berbeda sumbernya. Hukum acara perdata bersumber pada HIR, RBG dan BW, sedangkan Pengadilan dalam Islam bersumber pada kaidah Islam dengan sumber hukumnya mengacu pada Al Quran diatur dalam QS Al-Maidah (5) ayat 48 (maka putuskan hukum sesuai dengan wahyu yang diturunkan Allah) ${ }^{16}$. Perbedaan yang lain adalah hukum acara perdata tidak mengatur tetang peradilan khusus orang Islam melainkan peradilan secara umum. Peradilan khusus bagi orang Islam diatur khusus dengan Undang- Undang Nomor 7 Tahun 1989 diperbarui dengan Undang-Undang Nomor 3 tahun 2006 di perbarui lagi dengan Undang-Undang Nomor 50 tahun 2009 tetang Peradilan Agama. Undang- Undang Nomor 7 Tahun 1989 diperbarui dengan Undang-Undang Nomor 3 tahun 2006 diperbarui lagi dengan Undang-Undang Nomor 50 Tahun 2009 tentang Peradilan Agama ditetapkan berdasarkan dan berseumber pada kaidah-kaidah Islam yang ada dalam Al-Quran. Dengan demikian apabila penyelesaian sengketa ekonomi Syariah hanya mendasarkan pada hukum acara perdata saja, maka sebenarnya tidak bisa menyelesaikan sengketa ekonomi Syariah, mengingat hukum acara

15 Ibid., hlm.204

16 Anwar Sadat, 2010, Eksitensi Hakim menurut Al-Quran, AL-FIKR, Volume 14 Nomor 3 Tahun 2010. 
perdata sumber utamanya adalah undang-undang dan tidak mendasarkan pada kaidah Islam.

Bahwa terkait proses pemeriksaan yang dilakukan oleh hakim dalam hukum acara perdata (HIR dan RBG) tidak mengatur tetang kreteria hakim secara khusus, berbeda dengan kaidah Islam dalam buku sumber fiqih Usul Fiqih Buku XI disebutkan bahwa hakim adalah orang yang diangkat oleh pemerintah yang diberi tugas untuk menyelesaikan sengketa dan memutus terkait hukum suatu perkara dengan adil. ${ }^{17}$ Hakim harus adil sebagaimana Sabda Rasullah SAW, Apabila seorang hakim berlaku adil, maka dua malaikat membenarkan, menolong dan menunjukkan selama ia tidak menyeleweng, apabila hakim menyeleweng maka malaikat akan meninggalkanya". Sebagaimana diriwayatkan dalam Hadis al baihaqi ${ }^{18}$ dalam kaidah Islam diatur tentang syarat menjadi seorang hakim, antara lain:

1. Beragama Islam (tidak boleh menyerahkan pengurusan terkait penyelesaian sengketa kepada hakim yang bukan beragama Islam).

2. Balig dan beragama Islam.

3. Merdeka.

4. Bisa berbuat adil.

5. Seorang laki-laki berdasarkan Firman Allah SWT QS. An -Nisa: 34 dan Al Hadis, Rasulullah bersabda "suatu kaum yang menyerahkan urusan pada orang perempuan tidak akan bahagia" HR. Al Bukhori.

6. Memahami dan menguasai hukum Al Quran dan Hadis.

7. Memahami Ijmak Ulama.

8. Memahami bahasa Arab.

9. Memahami metode ijtihad sebagaimana Firman Allah dalam Al Quran Al-Isra: 36 ("Dan janganlah kamu mengikuti apa yang kamu tidak mempunyai pengetahuan tetangnya. Bahwasanya pendengara, penglihatan dan hati kesemuanya itu akan dimintai pertanggung jawaban");

10. Memiliki ingatan yang kuat.

Dalam hukum acara perdata (HIR dan RBG) tidak diatur terkait tetang kriteria hakim, pengaturan hakim justru diatur dalam peraturan Mahkama Agung dan Undang-Undang Pengadilan Agama. Syarat-syarat Hakim sebagaimana

\footnotetext{
17 Bacaan Madani, 2017, Pengertian Hakim, Syarat, Kedudukan dan Macam-Macam Hakim dalam Islam, https://www.bacaanmadani.com/2017/08/pengertian-hakim-syarat-kedudukan-dan.html 18 Ibid.
} 
diatur dalam Undang-Undang Nomor 3 Tahun 2006 Pasal (1) $13^{19}$ adalah sebagai berikut:

1. Warga negara Indonesia

2. Beragama Islam

3. Bertaqwa kepada Tuhan Yang Maha Esa

4. Setia kepada pancasila dan Undang-undang Dasar Negara Republik Indonesia Tahun 1945

5. Sarjana syariah dan atau sarjana hukum yang menguasai Islam

6. Berwibawa, jujur, adil dan berkelakuan tidak tercela

7. Sehat jasmani dan rohani

8. Bukan anggota organisasi terlarang

Di dalam Undang-Undang Nomor 3 Tahun 2006, pengaturan terkait kriteria hakim sudah memasukan beberapa unsur kaidah-kaidah Islam dalam pengaturan hakim untuk menyelesaikan sengketa ekonomi syariah meskipun tidak secara sepesifik sama dengan kaidah-kaidah Islam, akantetapi disesuaikan dengan perkembangan zaman terkait tetang kedudukan hakim wanita dalam Islam. Di dalam kaidah Islam sendiri, ada beberapa pendapat ada yang membolehkan Hakim wanita dan ada yang melarang. Fakta ini diungkapkan berdasarkan sejarah kedudukan hakim zaman Rasullulah SAW ${ }^{20}$. Pada zaman Rasullulah SAW, hakim diangkat selain sebagai juru hukum, sekaligus juga sebagai pemimpin umat ${ }^{21}$. Kemudian kedudukan hakim mengalami perkembangan, yakni hakim bukan lagi sebagai pemimpin umat melainkan khusus sebagai juru hukum. Dengan perkembangan ini, maka ada sebagian ulama yang membolehkan jabatan hakim di pegang oleh kaum wanita.

Dalam proses penyelesaian sengketa dalam tahap pembuktian kedua peraturan dalam hukum acara perdata (HIR dan RBG) dan kaidah Islam samasama menganut terkait tetang pembuktian, yang membedakannya adalah pada syarat saksi perkara. Kaidah Islam yang bersumber pada Al Quran menentukan bahwa syarat utama sebagai saksi adalah Islam; Baliq; Berakal; Adil; Meyaksikan secara langsung; Bisa berbicara, baik ingatan dan teliti.

Adapun macam-macam alat bukti dalam antara Hukum Perdata dan Hukum Islam juga berbeda. Menurut Hukum Islam alat bukti ada tujuh macam yaitu: Al Iqrar; Al BAyyinah; Al Yamin; An Nukul; Al Qosamah; Ilmu Pengetahuan Hakim; dan Qorinah. Sedangkan menurut Abdul Karim Zaidan, Alat -alat bukti

\footnotetext{
19 Undang-Undang Nomor 3 Tahun 2006 Tentang Perubahan Atas Undang-Undang Nomor 7 Tahun 1989 Tentang Peradilan Agama

20 Republika, 2015, Kedudukan Hakim Dalam Pandangan Islam, Jumat 23 Oktober 2015 16:00 WIB, https://www.republika.co.id/berita/koran/dialog-jumat/15/10/23/nwo10f15-kedudukan-hakimdalam-Islam, diakses pada hari Senin, 19 Nopember 2018 pukul 20.10 WIB.

${ }_{21}^{1}$ Ibid.
} 
ada sembilan dengan urutan sebagai berikut: Pengakuan, saksi, sumpah, Penolakan sumpah, Pengetahuan hakim, Qorinah, Qosanah, Qifayah, dan Qur'ah.

Sedangkan menurut Hukum Perdata pengertian pembuktian adalah mepertimbangkan secara logis kebenaran suatu fakta/pristiwa berdasarkan alatalat bukti yang sah dan menurut hukum pembuktian yang berlaku.22 Alat -alat bukti dalam perkara perdata diatur dalam Pasal 164 HIR/Pasal 284 R.Bg. yaitu: alat bukti surat; alat bukti saksi; alat bukti persangkaan; alat bukti pengakuan; alat bukti sumpah; pemeriksan ditempat diatur dalam Pasal 153 HIR/Pasal 180 R.Bg.; Saksi Ahli Pasal 154 HIR/Pasal 181 R.Bg.; PembukuanPasal 167 HIR/Pasal 296 R.B.g; dan Pengetahuan Hakim diatur dalam Pasal 178 (1) HIR, Undang-Undang Tentang Mahkamah Agung ${ }^{23}$.

Berkaitan dengan saksi dalam Islam jelas diatur terkait beban pembuktian saksi yaitu 2 orang laki-laki dan satu orang laki-laki dan dua orang perempuan. Sedangkan dalam hukum acara perdata pengaturan saksi terdapat dalam Pasal 168-172 HIR, syarat-syarat saksi-saksi harus memenuhi syarat formil dan materiil utuk bisa menjadi saksi. Syarat formil saksi antara lain:

1. Berusia 15 tahun keatas

2. Sehat kejiwaan atau aklaqnya

3. Tidak ada hubungan darah dan keluarga semenda dari yang bersangkutan. Kecuali undang-undang menentukan lain.

4. Tidak ada hubungan perkawinan

5. Tidak ada hubungan kerja

6. Mengankat sumpah menurut agamanya

7. Berjumlah sekurang-kurangnya dua

8. Dipangil diruang sidang satu persatu atau bergantian

9. Memberi keterangan secara lesan

Sedangkan Syarat Materiil sebagai saksi adalah:

1) Menernagkan apa yang dilihat, ia dengan dan ia alami sendiri (diatur dalam Pasal 171 HIR)

2) Saksi mengetahui pristiwa atau kejadian perkara

3) Bukan merupakan pendapat atau kesimpulan kesaksianya

4) Saling bersesuaian satu dengan yang lainnya

5) Tidak bertentangan dengan akal sehat. ${ }^{24}$

Bahwa terkait syarat saksi harus Islam ada dua pendapat dalam kaidah Islam, pendapat yang menyatakan saksi harus laki-laki juga ada dasarnya baik

\footnotetext{
${ }^{22}$ Mukti Arto, op. cit., hlm 139

23 Ibid., hlm 145.

24 Ibid., hlm 166.
} 
dalam Al Qur'an atau dalam Al Kadis yaitu prinsip umum yang telah disepakati oleh seluruh ahli hukum Islam, saksi itu harus beragama Islam. Surat al-Hujarat ayat 6 yang artinya: "Hai orang-orang yang beriman, apabila datang kepadamu orang fasiq membawa suatu berita maka periksalah dengan teliti agar kamu tidak menimpakan suatu musibah kepada suatu kaum tanpa mengetahui keadaanya......", dan saksi disyaratkan 2 orang laki-laki. Ketentuan saksi ini berdasarkan firman Q.S. al-Baqarah: 282, yang artinya: "dan persaksikanlah dengan dua orang saksi dari orang-orang lelaki (diantara kamu). Jika tidak ada dua orang laki-laki, maka boleh seorang laki-laki dan dua orang perempuan dari saksi-saksi yang kamu senangi...".

Syarat saksi dalam hukum acara perdata tidak membedahakan terkait agama, dan terkait saksi yang tidak bisa berbicara dalam hukum acara perdata boleh asalkan memenuhi kreteria saksi yaitu menerangkan apa yang dia lihat, dengar dan alami sendiri Pasal 171 (1) HIR, bukan pendapat atau kesimpulan saksi, saling bersesuaian satu dengan yang lain berakal sehat. ${ }^{25}$ Kedudukan saksi dalam hukum Islam diatur berdasarkan Al-Quran dan Al Kadis, dalam hukum acara perdata ada perbedaan pijak atau dasar pengaturannya. untuk perihal alat bukti saksi kaidah Islam dengan hukum acara perdata berbeda akan tetapi dalam penerapan dilapangan pada peradilan agama pembuktianya menggunakan sistem hukum acara perdata. Berdasarkan dari penelitian terkait pembuktian ada perbedaan dalam dasarnya atau sumbernya sehingga produk yang dihasilkan bentuk sama tetapi mempunyai kandungan yang berbeda.

Tahap pengambilan keputusan dalam hukum acara perdata dengan kaidah Islam perbedahanya terkait sumber penemuan hukum. Hukum acara perdata bersumber pada peraturan perundang-undangan, hukum kebiasan, Yurisprudensi, Trakta atau perjanjian Internasional, Doktrin dan sumber lainya. Sedangkan kaidah Islam selalu mendasarkan kepada empat macam rujukan yang disepakati oleh mayoritas kaum Islam (dari yang paling utama) yaitu: Kitab Al Quran, sunna, ijimak, dan qiyas. Penetapan empat sumber hukum ini tertera dalam firman Allah dalam Surah An-Nisa'.

Hukum formal atau hukum acara perdata (HIR ,RBG dan BW) mendasarkan pada hasil perbandingan hukum tersebut, nilai-nilai syariah tidak ada dalam proses beracaranya. Untuk memenuhi nilai-nilai syariah harus merujuk pada peraturan-peraturan di luar hukum acara perdata, antara lain UndangUndang Peradilan Agama, Peratuan Mahkamah Agung, Fatwa DSN, Peraturan BI, Peratuan OJK dan peraturan-peraturan lainya yang tersebar di berbegai peraturan perundang-undangan. Penyelesaian sengketa khususnya ekonomi syariah dengan menggunakan hukum acara perdata yang berdasarkan pada HIR, RBG dan BW proses beracaranya memakan waktu yang masih terkesan lama.

${ }^{25}$ Ibid. 
Asas peradilan cepat, sederhana biaya murah ${ }^{26}$ belum tercermin dalam proses beracara menggunakan hukum acara perdata, dan rata-rata penyelesaian sengketa ekonomi syariah memerlukan waktu 5-6 bulan di tingkat pertama di Pengadilan Agama. Apabila ditambah waktu upaya hukum banding dan kasasi, maka waktunya bisa menjadi lebih lama. Sehingga asas cepat kurang terpenuhi dalam tahap pemeriksaan sengketa ekonomi syariah dengan mengunakan hukum acara perdata atau lebih dikenal dengan proses penanganan biasa, karena memakan waktu yang lama. Dengan demikian dapat dikatakan bahwa penyelesaianya tidak efisien secara prosedural dan implikasinya memakan biaya yang mahal. Sementara dalam kaidah Islam mengharuskan proses penanganan perkara dianjurkan cepat, sederhana dan murah.

Hal yang lain adalah terkait dengan wanprestasi dan perbuatan melawan hukum ada perbedahan secara mendasar. Menurut KHUPerdata, apabila satu pihak melakukan wanprestasi atau perbuatan melawan hukum, maka pihak yang merasa dirugikan dapat melakukan penuntutan terkait ganti rugi biaya pemulihan prestasi, ganti rugi, serta bunga. Akantetapi dalam hukum Islam tuntutan ganti rugi tidak boleh disertakan dengan tuntutan pembayaran bunga. Dan dalam hukum Islam tidak mengenal kerugian immateriil dikarenakan letak ukuran untuk menghitung kerugian immaterial tidak jelas.

Bahwa berdasarkan dari hasil penelitian antara kurun waktu 2006 sampai 2016 tersebut, penyelesaian sengketa ekonomi syariah bisa berjalan meskipun belum ada hukum formilnya yang secara khusus mengaturnya. Hukum Formal yang digunakan adalah hukum acara perdata, dimana hukum acara perdata dalam dataran tersebut bersumber dari hukum HIR, RBG dan BW dimana ketiga sumber hukum tersebut sebagaimana diuraikan di atas ditinjau dari penerapan hukum formilnya tidak memuat kententuan ketentuan Syariah, dikarenakan sumber dari ketentuan hukum tersebut bukan dari Al quran dan kadis. Jika peraturan tersebut diterapkan dalam penyelesaian sengketa ekonomi Syariah, maka tidak akan pernah sesuai. Maka untuk mengisi kekosongan peraturan tersebut, seharusnya diterbitkan peraturan-peraturan lain sebagai penunjang pemenuan prinsip Syariah, dan peraturan tersebut banyak macamnya. Dilihat dari segi peraturan hukum formal atau hukum acara pada periode tersebut belum ada aturan hukum yang terkodifikasi dan tersusun secara komprehensip terkait hukum acara ekonomi Syariah.

Bahwa dalam periode tersebut peraturan hukum acara bisa dikatakan dari sisi peraturan yang masih tersebar belum ada peraturan yang khusus mengatur hukum acara sebagaimana dalam sengketa perkawinan sudah mempunyai hukum acara tersediri atau aturan khusus yang menyimpang dari ketentuan hukum acara pedata pada umumnya yaitu terkait pengaturan saksi ${ }^{27}$. Jika dilihat

${ }^{26}$ Ibid., hlm.9

27 Ibid., hlm 12 
dari obyek sengketa ekonomi syariah memiliki kekusussan tersendiri yaitu adanya pringsip syariah yang melekat dalam setiap kegiatan ekonomi syariah. seharusnya dibarengi degan peraturan formalnya yang berdasarkan nilai-nilai syariah. mekanisme penyelesaian sengketa yang masih sama dengan sengketa pada umumnya tidak singkrong dengan hukum materiilnya, dalam kegiatan ekonomi dibutuhkan ketepatan dan efisiensi prosedur acara. Tetapi dalam priode tersebut penyelesaian sengketa ekonomi syariah masih berifat konvensional tidak pridiktif. Sehingga proses penanganan sengketa dalam priode tersebut bisa dikatakan mengadung ketidak pastian hukum dalam priode awal karena membuka peluang pengadilan lain dapat menangani sengketa ekonomi Syariah, seperti terlihat dari Undang-Undang Nomor 21 tahun 2008 tentang Perbankan Syariah yang memberikan peluang bagi penyelesaian sengketa ekonomi Syariah sesuai isi akad. ${ }^{28}$

Sebenarnya kedudukan hakim sangat penting dalam menyelesaikan persoalan ketiadaan hukum acara penyelesaian sengketa ekonomi Syariah. Hakim sebagai pihak yang ditugasi untuk memutus perkara sengketa ekonomi syariah untuk mengisi kekosongan hukum, maka hakim dapat berperan dengan melakukan terobosan hukum yang diijinkan oleh undang-undang yaitu dengan melakukan Ijtihad. Jika dalam satu perkara tidak ditemukan aturan hukum dengan bersumber kepada al quran dan Kadis juga melihat kearifan lokal yang ada, sehingga dapat menghasilkan keputusan yang adil.

\subsection{Tata Cara Penyelesaian Sengketa Ekonomi Syariah Setelah Lahirnya Peraturan Mahkamah Agung Nomor 14 Tahun 2016 Sesuai Degan Nilai-Nilai Syariah.}

Lahirnya Peraturan Mahkamah Agung Nomor 14 Tahun 2016 tetang Tata Cara Penyelesaian Sengketa Ekonomi Syariah berdasarkan dari hasil penelitian bahwa lahirnya perma tersebut dalam sisi waktu terlalu lama dari peraturan yang mengatur tetang kewenangan Pengadilan Agama menyelesaikan sengketa ekonomi syariah, yaitu Undang-Undang Nomor 3 Tahun 2006, dibutuhkan waktu kurang lebih 10 tahun. Perma tersebut dalam dataran pelaksanaan merupakan produk aturan yang digolongkan sebagai hukum formil ekonomi Syariah. Perlu dikaji juga apakah Perma Nomor 14 Tahun 2016 sebagai hukum formil atau hukum acara dalam sisi aturanya berbeda dengan hukum acara perdata (HIR dan Rv) yang terlebih dahulu dipakai sebagai hukum acara. Dalam Penelitian ini penulis akan uraikan mekanisme beracara menurut Perma Nomor 14 Tahun 2016 dan Hukum Acara Perdata pada tabel 2.

${ }^{28}$ Amran Saudy, op. cit., hlm. 50. 
Tabel 2. Mekanisme beracara menurut Perma Nomor 14 Tahun 2016

\begin{tabular}{|c|c|c|}
\hline Aspek/Jenis & Cara Sederhana & Cara biasa \\
\hline Nila/Besarnya Gugatan & $\begin{array}{lll}\text { Maksimal } & R p & 200 \\
\text { juta } & & \end{array}$ & $\begin{array}{l}\text { Lebih dari Rp } 200 \text { Juta nilai } \\
\text { gugatannya.jika dalam } \\
\text { Hukum acara Perdata tidak } \\
\text { mengenal Perbedahan nilai } \\
\text { perkara. }\end{array}$ \\
\hline $\begin{array}{l}\text { Domisili para pihak dalam } \\
\text { perkara }\end{array}$ & $\begin{array}{lr}\text { Penggugat } & \text { dan } \\
\text { Tergugat } \\
\text { berdomisili } \\
\text { wilayah } & \text { di } \\
\text { yang sama } & \end{array}$ & $\begin{array}{l}\text { Penggugat dan Tergugat } \\
\text { tidak harus berdomisili di } \\
\text { wilayah hukum yang sama }\end{array}$ \\
\hline $\begin{array}{l}\text { Terkait jumlah para pihak } \\
\text { dalam berperkara }\end{array}$ & $\begin{array}{l}\text { Penggugat dan } \\
\text { Tergugat masing- } \\
\text { masing tidak boleh } \\
\text { lebih dari satu, } \\
\text { kecuali punya } \\
\text { kepentingan hukum } \\
\text { yang sama }\end{array}$ & $\begin{array}{l}\text { Penggugat dan tergugat } \\
\text { masing-masing boleh lebih } \\
\text { dari satu }\end{array}$ \\
\hline Alamat tergugat & Harus diketahui & Tidak harus diketahui \\
\hline Pendaftaran Perkara & $\begin{array}{l}\text { Menggunakan } \\
\text { blanko gugatan }\end{array}$ & Membuat surat gugatan \\
\hline Pengajuan bukti-bukti & $\begin{array}{l}\text { Harus bersamaan } \\
\text { dengan pendaftaran } \\
\text { perkara }\end{array}$ & $\begin{array}{l}\text { Pada saat sidang beragenda } \\
\text { pembuktian }\end{array}$ \\
\hline 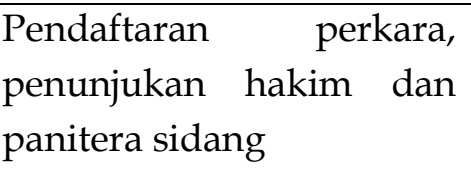 & Paling lama 2 hari & Paling lama hari 1 bulan \\
\hline Pemeriksaan dan pemutus & Hakim tunggal & Majelis hakim \\
\hline $\begin{array}{l}\text { Pemeriksaan } \\
\text { pendahuluan }\end{array}$ & Ada & Tidak ada \\
\hline Mediasi & Tidak ada & Ada \\
\hline
\end{tabular}




\begin{tabular}{|c|c|c|}
\hline Kehadiran para pihak & $\begin{array}{lr}\text { Penggugat } & \text { dan } \\
\text { tergugat } & \text { wajib } \\
\text { menghadiri } & \text { setiap } \\
\text { persidangan } & \text { secara } \\
\text { langsung } & \\
\text { (impersonal), } & \text { meski } \\
\text { punya } & \text { kuasa } \\
\text { hukum } & \end{array}$ & $\begin{array}{l}\text { Penggugat dan tergugat tidak } \\
\text { wajib menghadiri setiap } \\
\text { persidangan secara langsung } \\
\text { (impersonal) bisa dikuasakan }\end{array}$ \\
\hline $\begin{array}{l}\text { Konsekwensi } \\
\text { ketidakhadiran penggugat } \\
\text { pada sidang pertama } \\
\text { tanpa alasan yang sah }\end{array}$ & $\begin{array}{l}\text { Gugatan } \\
\text { dinyatakan gugur }\end{array}$ & $\begin{array}{l}\text { Gugatan tidak dinyatakan } \\
\text { gugur }\end{array}$ \\
\hline Dalam Pembuktian & $\begin{array}{l}\text { Di bolehkan dengan } \\
\text { menggunakan } \\
\text { sarana teknologi } \\
\text { informasi dalam } \\
\text { proses pendaftaran } \\
\text { dan pembuktian }\end{array}$ & Tidak diatur \\
\hline Kuwalifikasi Hakim & $\begin{array}{l}\text { Harus mempunyai } \\
\text { sertifikasi hukum } \\
\text { ekonomi syariah }\end{array}$ & Pengaturanya belum jelas \\
\hline $\begin{array}{l}\text { Putusan terkait } \\
\text { pertimbangan hukum }\end{array}$ & 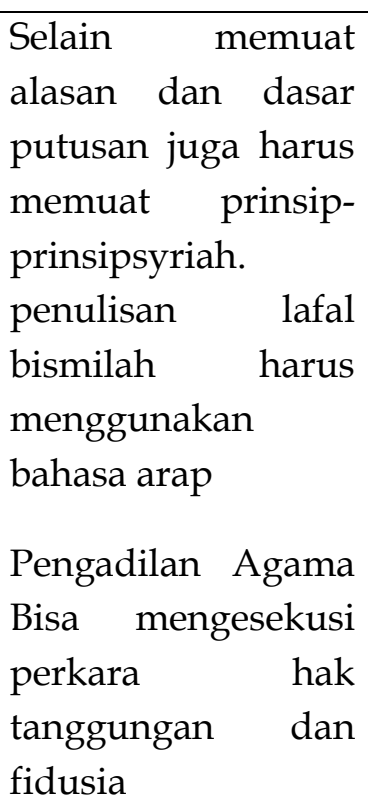 & $\begin{array}{l}\text { Pengaturan mendasarkan } \\
\text { pada alasan dan } \\
\text { pertimbangan hukumnya. } \\
\text { Tidak mengaturnya. } \\
\text { Belum diatur. }\end{array}$ \\
\hline
\end{tabular}


Berdasarkan tabel di atas penyelesaian sengketa ekonomi Syariah menurut Perma dan hukum acara perdata ada perbedaan, yaitu dalam Perma tersebut membedakan pelaksanaan penyelesaian sengketa dengan membedakan besar kecilnya obyek sengketa. Sedangkan Hukum acara perdata tidak membedakan, karena dalam hukum acara perdata hanya mengenal satu penyelesaian sengketa dengan acara biasa. Perma memperbolehkan penggunaan sarana informasi berbasis teknologi dalam pemanggilan para pihak, juga dalam tahap pembuktian yang bisa digunakan sarana informasi teknologi dalam hal hakim bisa meminta keterangan Ahli dengan bantuan sarana informasi teknologi..29 Sedangkan dalam hukum acara perdata tidak mengenal hal tersebut. Tetang tulisan lafal "Bismillah" dalam Perma ini ditegaskan penulisan di tulis dengan memakai huruf Arab dalam penyelesaian sengketa Syariah, sementara dalam pemeriksaan biasa tidak disebutkan harus ditulis dengan huruf apa. Perbedaan lainnya pelaksanaan putusan terkait eksekusi hak tanggungan dan fidusia menjadi kewenangan Pengadilan Agama ${ }^{30}$, dan yang paling penting Perma tersebut lahir disesuaikan dengan hukum materiilnya yang terlebih dahulu dibuat yaitu Kompilasi Hukum Ekonomi Syariah yang lahir tahun 2008 sehingga aturan hukum atau pijakan hukumnya mempunyai nilai-nilai yang sama degan hukum materiilnya. Yang paling menonjol dalam Perma Nomor 14 Tahun 2016 tersebut asas hukum Peradilan Agama yaitu, cepat, sederhana dan murah terlihat jelas waktu penyelesaian perkara Syariah kurang dari 25 hari dan pemeriksaan sederhana tersebut harus segera diputus. Terkait penerapan nilai-nilai Syariah dalam Perma Nomor 14 Tahun 2019 berdasarkan dari hasil penelitian tersebut pada Tabel 3 dibawah ini.

Tabel 3. Tahapan beracara berdasarkan Perma Nomor 14 Tahun 2016 dan Kaidah Islam

\begin{tabular}{|c|c|c|}
\hline Aspek/Jenis & $\begin{array}{l}\text { Perma Nomor } 14 \text { Tahun } \\
2016\end{array}$ & Kaidah Islam \\
\hline Tahap Pemeriksaan & $\begin{array}{lr}\text { Tahap } & \text { Pemeriksaan } \\
\text { dengan membedahkan } \\
\text { besar kecilnya obyek } \\
\text { sengketa, } \\
\text { dilaksanakan dan } \\
\text { singkat kurang lebih } 25 \\
\text { hari. Dikenal dengan }\end{array}$ & $\begin{array}{l}\text { Dalam Kaidah Islam Al } \\
\text { Quran surat } \mathrm{Al} \text { Baqarah } \\
\text { ayat } 186 \text { menyaratkan } \\
\text { bahwa Allah menghendaki } \\
\text { kemudahan bagimu dan } \\
\text { tidak menghendaki } \\
\text { kesukaran bagimu. kontek }\end{array}$ \\
\hline
\end{tabular}

\footnotetext{
29 Wawan Muhwan Hariri, 2011, Hukum Perikatan, Bandung, Pustaka Setia, hlm. 337.

30 Peraturan Mahkamah Agung Nomor 14 Tahun 2016 tentang Tata Cara Penyelesaian Sengketa Ekonomi Syariah Pasal 5
} 


\begin{tabular}{|l|l|lr|}
\hline & $\begin{array}{l}\text { istilah pemeriksaan } \\
\text { sederhana31 }\end{array}$ & $\begin{array}{l}\text { ayat ini bisa di artika } \\
\text { dalamkaidah }\end{array}$ \\
disyaratkan Islam \\
dalampenyelesaian \\
sengketa dengan acara \\
sederhana.
\end{tabular}

${ }^{31}$ Amran Saudy, op. cit. hlm.116

32 Ibid., hlm.122

33 Perma Nomor 14 tahun 2016 
Lahirnya Perma nomor 14 Tahun 2016 tentang Tata Cara Penyelesaian Sengketa Ekonomi Syariah dalam pengaturanya telah sinkron dengan hukum materiilnya, sehingga sesuai dalam dataran pelaksanaanya. Berdasarkan hasil penelitian hukum formal atau hukum acara dalam kontek hukum dalam peraturan perundang-undang belum mengatur secara jelas terkait ukuran nilainilai Syariah dalam proses beracara. Sementara dalam Perma ini dijelaskan dalam ketentuan umum terkait prinsip Syariah adalah prinsip hukum Islam dalam kegiatan ekonomi syariah berdasarkan fatwa yang di keluarkan oleh lembaga yang berwenang mengeluarkan fatwa di bidang syariah ${ }^{34}$. Bisa difahami bahwa pringsip syariah yang ditekankan disini adalah kegiatan ekonominya atau obyeknya atau hukum materiilnya. Jika hukum materiilnya telah sesuai dengan hukum Islam maka hukum fomilnya akan mengikuti. Hal tersebut ditekankan dalam Pasal 54 Undang-Undang Nomor 7 Tahun 1989 tetang Peradilan Agama menyebutkan" Hukum acara yang berlaku pada Pengailan dalam lingkungan Peradilan Agama adalah Hukum Acara Perdata yang berlaku pada Pengadilan dalam lingkungan Peradilan umum "kecuali" yang telah diatur secara khusus dalam undang-undang ini. ${ }^{35}$ Pengertian "kecuali" di atur secara khusus adalah dalam hukum perkawinan berlaku hukum acara khusus. Selebihnya menggunakan hukum acara perdata. Terkait pengertian Pasal di atas menurut pendapat penulis berdasarkan dari hasil penelitian kurang setuju, karena hukum acara perdata yang berlaku hampir sama dengan hukum acara perdata pada pengadilan umum. Berdasarkan penelusuran penulis bahwa hukum acara perdata yang bersumber dari HIR dan Rv tersebut berbeda ruhnya dengan kaidah Islam sumber dari kaidah Islam adalah Al quran dan sunna. Hukum perdata sumbernya HIR dan Rv atau bersumber hukum yang dibuat oleh pemerinta Belanda, untuk perkara kegiatan ekonomi secara konvensional tidak masalah akan tetapi jika digunakan untuk menyelesaikan sengketa ekonomi syariah tidak sesuai karena hukum acara perdata ruhnya tidak dibuat secara khusus untuk menegakkan hukum ekonomi syariah yang mengandung prinsip-prinsipsyariah. Sehingga kurung waktu sebelum lahirnya Perma tersebut, penggunaan hukum perdata bisa berjalan dengan catatan adanya peraturan lain sebagai sumber hukum pendamping selain hukum acara perdata, sumber hukum lain tersebut tersebar dibeberapa peraturan baik peraturan Perundang-Undangan atau peraturan dibawah Undang-Undang dan peraturan tersebut berfungsi untuk memberikan ruh prinsip-prinsip syariah dalam pelaksanaan penyelesaian sengket ekonomi syariah agar memuat ketentuan nilai-nilai syariah. Lain halnya dengan Perma Nomor 14 Tahun 2016 bahwa aturan tersebut lahir atas permasalahan di atas sehingga diperluhkan aturan hukum yang mampu menghadirkan nilai-nilai syariah dalam penegakkan hukum materiilnya. Meskipun aturan tersebut masih

34 Ketentuan Umum Perma Nomor 14 Tahun 2016.

${ }^{35}$ Mukti Arto, Op. Cit, hlm. 7. 
bersifat Perma untuk penanganan sengketa ekonomi syariah khususnya sengketa perbangkan, Perma tersebut sangat membantu bagi hakim dalam memeriksa dan memutus sengketa ekonomi syariah. Adanya pemeriksaan sederhana dengan waktu 25 hari merupakan trobosan hukum yang sesuai dengan kaidah hukum Islam dalam hukum acara perdata tidak dikenal. Adanya pemeriksaan pendahuluan hal tersebut sesuai dengan kaidah Islam hakim wajib mengadili perkara dengan sikap kehati-hatian. Penggunaan sistem teknologi informasi dalam proses pendaftaran dan alat bukti hal tersebut sesuai dengan era kegiatan ekonomi saat ini yang baru dengan ekonomi digital yaitu kegiatan ekonomi berbasis teknologi dalam kaidah Islam bayak mengatur tentang ayat-ayat yang menangkap kemajuan teknologi dalam Al Quran ada beberapa ayat yang mengisyaratakan manusia harus mempelajari teknologi dalam rangka mempelajari kebesaran Allah SWT. dalam putusan ditekankan harus bersumber Al Quran dan Al Kadis (mengadung prinsip-Prinsip Syariah) baru peraturan lain jika kedua sumber tesebut tidak mengaturnya.

Kedudukan Perma sebagai aturan dalam pelaksanaan penyeleaian sengketa ekonomi syariah jika dilihat dari kewenangan atau cakupan kegiatan ekonomi syariah yang luas diatur dalam Pasal 49 huruf (i) Undang-Undang Nomor 3 tahun 2006, bahwa Pengadilan Agama bertugas dan berwenang memeriksa, mengadili dan menyelesaikan perkara di tingkat pertama antara orang-orang yang beragama Islam dalam bidang ekonomi syariah yang meliputi bank syariah, lembaga keuangan mikro syariah, asuransi syariah, reasuransi syariah, reksadana syariah, obligasi syariah dan surat berharga berjangka menengah syariah, sekuritas syariah, pembiayaan syariah, pegadaian syariah, dana pensiun lembaga keuangan syariah, dan bisnis syariah. ${ }^{36}$, belum cukup di karenakan peraturan yang terdapat dalam Perma Nomor 14 tahun 2016 masih bersifat umum belum mencakup secara lengkap terkait hukum acara.Jika dilihat luasnya cakupan kegiatan ekonomi tersebut. Diperluhkan produk aturan yang lebih luas dan mencakup semua hal.

Untuk menunjang hukum materiilnya yang telah dibentuk berupa Kompilasi Hukum Ekonomi Syariah 2008. Mahkamah Agung sebenarnya telah membuat rancangan terkait Hukum Acara Ekonomi Syariah. Hal ini dilakukan dengan dimulai pada tahun 2010 dengan adanya Surat Keputusan Ketua Mahkama Agung RI Nomor 151/KMA/SK/VIII/2010 terkait penunjukan Tim Penyusun Hukum Acara Ekonomi Syariah dalam SK tersebut menunjuk Prof Dr.H.Abdul Manan S.H.,,SIP.,M.Hum sebagai Ketua Pokja. Selanjutnya pada tahun 2011 di bentuk tim kecil dengan dasar Surat Keputusan Mahkamah Agung RI Nomor 001/Tim HAES/II/2011. Berdasarkan SK tersebut maka tim kecil bekerja menyusun Rancangan Kompilasi Hukum Acara Ekonomi Syariah, tugak tim kecil adalah mengumpulkan bahan-bahan yang dibutuhkan, menyusun

36 Suhartana, 2011, Proses Legislasi Fikih Muamalah dalam Sistem Hukum Nasional, http://artikel.badilag.net diakses pada hari Senin, 19 November 2018 pukul 20.10 WIB 
naskah akademik, menyusun draf KHES dan melakukan stady banding dan memerlukan waktu yang panjang. Pada tanggal 13 Desember 2012 di Hotel Royal Safari Garden Cisaruah Bogor tersusun lah Kompilasi Hukum Ekonomi Syariah dengan jumlah Pasal seluruhnya sebanyak 263 Pasal dengan sistematika ${ }^{37}$ sebagai berikut:

1. Mukhadimah:

2. Bab I, Ketetuan Umum, terdiri dari dari empat bagian, dari Pasal 1` sampai dengan Pasal 18;

3. Bab II, Tuntutan Hak, terdiri dari dua bagian dari Pasal 18 s.d.Pasal 27:

4. Bab III, Pemberian kuasa Khusus, dari Pasal 28 s.d.Pasal 38:

5. BAb IV, Pendaftar, Penetan Hari Sidang, dan Tata CaraPemanggilan, terdiri dari dua bagian, dari Pasal 39 s.d. Pasal 46:

6. Bab V, Upaya Menjamin Hak, terdiri dari dua bagian, Pasal 47 s.d. Pasal 58:

7. Bab VI, Perdamian dan Mediasi, dari Pasal 59 s.d. Pasal 63:

8. Bab VII, Tata Cara Pemeriksaan Perkara, dari Pasal 64 s.d. Pasal 90:

9. Bab VIII, Al-Bayyinah(pembuiktian), dariPasal 91 s.d. Pasal 149:

10. Bab IX, Putusan (Al-Hukumu), dari Pasal 150 s.d. Pasal 162:

11. BabX, Upaya Hukum, dari Pasal 163 s.d. Pasal 194:

12. Bab XI, Eksekusi Putusan, dari Pasal 195 s.d. Pasal 213

13. Bab XII, Acara Khusu, dari Pasal 214 s.d. Pasal 263

Bahwa Rancangan Hukum Acara Ekonomi Syariah tersebut secara subtansinya berlakunya sesuai hukum acara Perdata yang berlaku, dan rancangan Kompilasi Hukum Acara Ekonomi Syariah tersebut hampir sama dengan Rancangan Undang-Undang. Hal ini merupakan karya agung dari Mahkamah Agung meskipun dalam pelaksanaanya tidak bisa diakomodasi dengan bentuk Peraturan Mahkama Agung dan merupakan bagian dari awal mula lahirnya Peraturan Mahkamah Agung Nomor 14 Tahun 2016. Diharapkan Mahkamah Agung bisa segera menerbitkan Kompilasi Hukum Acara Ekonomi Syariah, yang dapat digunakan sebagai penunjang hukum materiilnya. Rancangan hukum acara ekonomi syariah secara implisit masih mengacu pada hukum acara perdata, akantetapi sudah memasuhkan unsur-unsur prinsip-prinsip syariah dalam hal pendaftaran perkara, proses beracara, pembuktian dan putusan. Perma nomor 14 tahun 2016 merupakan aturan yang diterbitkan oleh Mahkama Agung, sebagai tindak lanjut peraturan hukum materiilnya yaitu Kompilasi Hukum Ekonomi Syariah, yang lebih duluh terbit. Dalam dataran penyelesaian sengketa ekonomi syariah sudah singkron antara hukum materiil dan hukum acara, yaitu yang menonjol dalam Perma tersebut adanya penyelesaian sengketa sederhana diatur

${ }^{37}$ Amran Saudy, op. cit., hlm. 330-335. 
bagaimana proses beracara dari mulai pendaftaran, pemeriksaan dan putusan, yang sangat ketal mengusung asas peradilan cepat, sederhana dan biaya murah. ${ }^{38}$

Lahirnya Perma Nomor 14 Tahun 2016 memberi angin segar dan sekaligus sebagai jawaban atas ketidakpastian hukum dalam priode awal lahirnya penyelesaian sengketa ekonomi Syariah. Dalam Perma ketentuan umum nomor 5 meyebutkan Pengadilan adalah Pengadilan Agama, hal tersebut menegaskan pringsip syariah melekat pada aturan formalnya, yaitu wadah penyelesaian sengketa ekonomi syariah secara litigasi mejadi otoritas Pengadilan Agama. Dan semakin sempurna karena dalam Perma tersebut juga diatur bahwa pengadilan agama berhak melakukan eksekusi terkait putusan hak tanggungan dan fidusia hal tersebut diatur dalam Pasal 13.39 Hal ini menunjukkan bahwa kewenangan pengadilan agama semakin besar. Dan dalam tahap putusan Pasal 5 di jelaskan bahwa putusan dan penetapan pengadilan dalam ekonomi syariah alasan dasar putusan juga harus memuat prinsip-prinsipsyariah ${ }^{40}$. Hal ini menegaskan bahwa Perma terebut telah memenuhi nilai-nilai syariah sebagaimana amanat undangundang. meskipun secara hukum acara telah disesuaikan dengan Kompilasi Hukum Ekonomi Syariah, akan tetapi untukkedepanya harus segera dibuat hukum materiilnya yaitu akad akad Syariah harus ada pengaturan yang baku yang berladaskan nilai-nilai Syariah.

\section{Kesimpulan}

1. Hukum acara masih sama dengan hukum acara yang digunakan dalam penyelesaian sengketa di pengdilan umum, untuk memenuhi prinsipprinsipsyaiah harus di dukung dengan peraturan lain. Penyelesaian sengketa ekonomi Syariah wajib diselesaikan oleh hakim yang beragama Islam, untuk memenuhi nilai-nilai syariah dibutuhkan peraturn lain yang disesuaikan dengan kaidah Islam yaitu digunakan Undang-Undang Nomor 3 tahun 2006 tetang Peradilan Agama dalam Pasal 13 mengatur ketentuan syarat hakim harus beragama Islam.

2. Hukum acara Penyelesaian sengketa ekonomi Syariah belum terkodifikasi masih tersebar di beberapa peraturan lain, karena untuk menunjang pelaksanaan hukum acara supaya berjalan sesuai prinsip-prinsip syariah, bahwa pengaturan hukum acara harus sesuai dengan pringsip syariah tidak diatur secara jelas dalam Undang-Undang Nomor 3 tahun 2006 yang merupakan tonggak awal kewenangan Pengadilan Agama memeriksa sengketa ekonomi Syariah. Terkait dengan prinsip-prinsip syariah dalam UndangUndang Nomor 21 Ttahun 2008 Pasal 55 ayat (3) diatur prinsip syariah dalam hukum materiilnya.

\footnotetext{
38 Mukti Arto, Op.Cit, hlm .11

39 Perma nomor 14 Tahun 2016 Pasal 13

40 Ibid. Pasal 5
} 
3. Ukuran memenuhi prinsip-prinsipsyariah dalam hukum acara juga harus dijelaskan secara lengkap dan dimuat dalam peraturan, sehingga dalam dataran pelaksanaan hukum acara tolok ukurnya jelas yakni memenuhi ketentuann nilai-nilai Syariah. Ukuran pemenuhan nilai-nilai syariah tersebut diukur dengan tidak bertetangan dengan nash atau Al quran dan Sunnah. Akantetapi dalam pelaksanaan hukum acara (hukum formal) dari tahun 2006 sampai 2016, hukum acara formal yang digunakan adalah hukum acara perdata sebagaimana ketentuan dalam Pasal 54 Undang-Undang Nomor 7 Tahun 1989 tetang Peradilan Agama. Bahwa Hukum Acara Perdata yang digunakan jika hanya bersumber pada hukum acara perdata (HIR dan Rv), tidak bisa dipergunakan untuk penyelesaian sengketa ekonomi syariah karena tidak memenuhi nilai-nilai Syariah. Sehingga dapat dikatakan bahawa sejak tahun 2006 sampai dengan 2016 terjadi kekosongan hukum acara penyelesaian sengketa ekonomi Syariah. Kekosongan hukum ini membuka peluan penggunaan hukum lain selaian hukum acara untuk memenuhi nilai-nilai syariahnya.

4. Ketidakpastian hukum terjadi ketika ada kewenangan yang diberikan kepada pengadilan yang lain dapat menyelesaikan sengketa ekonomi Syariah, selain Pengadilan Agama itu sendiri. Kewenangan yang tidak diberikan kepada satu pengadilan menyebabkan putusan yang dihasilkan tidak bisa digunakan sebagai yurisprudensi.

5. Lahirnya Peraturan Mahkamah Agung Nomor 14 Tahun 2016, memberi teroboson dalam hukum acara. Bisa dikatakan bahwa Perma tersebut sebagai hukum formilnya sengketa ekonomi syariah untuk saat ini. Perma merupakan peraturan yang memuat ketetuan nilai-nilai syariah di atur dalam Pasal 5 bahwa semua putusan dan penetapan pengadilan harus menggunakan pringsip syariah. Memuat terobosan baru dalam penyelesaian sengketa ekonomi syariah dengan menggunakan prosedur beracara secara sederhana. Bahwa prosedur beracara tersebut sudah sesuai asas peradila cepat, sederhana dan murah, hal ini disesuaikan dengan kegiatan ekonomi syariah yang membutuhkan ketepatan, efisiensi dan biaya murah. Dalam Perma terbaru telah diatur kedudukan hakim dan syarat Hakim ekonomi syariah yang harus berkopeten dan bersertifikasi ekonomi syariah.

\section{Daftar Pustaka}

Amran Saudy, 2017, Penyelesaiian Sengketa Ekonomi Syaria Teori \& Praktek, Kencana. Mukti Arto, 1996, Praktek Perkara Perdata Pada Pengadilan Agama, Yogyakarta, Pustaka Pelajar.

Wawan Muhwan Hariri, 2011, Hukum Perikatan, Bandung, Pustaka Setia. 


\section{Jurnal:}

Anwar Sadat, 2010, Eksitensi Hakim menurut Al-Quran, AL-FIKR, Volume 14 Nomor 3 Tahun 2010.

Majalah Peradilan Agama, 2015, Perumusan KHES, Edisi 8 Desember 2015.

\section{Internet:}

Bacaan Madani, 2017, Pengertian Hakim, Syarat, Kedudukan dan Macam-Macam Hakim dalam Islam, https://www.bacaanmadani.com/2017/08/pengertian-hakimsyarat-kedudukan-dan.html

Republika, 2015, Kedudukan Hakim Dalam Pandangan Islam, Jumat 23 Oktober 2015 16:00 WIB, https://www.republika.co.id/berita/koran/dialogjumat/15/10/23/nwo10f15-kedudukan-hakim dalam-Islam, diakses pada hari Senin, 19 November 2018 pukul 20.10 WIB.

Suhartana, 2011, Proses Legislasi Fikih Muamalah dalam Sistem Hukum Nasional, http://artikel.badilag.net, diakses pada hari Senin, 19 November 2018 pukul 20.10 WIB.

\section{Peraturan Perundang-Undangan}

Kitab Undang-Undang Hukum Acara Perdata.

Undang - Undang Nomor 7 Tahun 1989 tentang Peradilan Agama.

Undang-Undang Nomor 3 Tahun 2006 Tentang Perubahan Atas Undang-Undang Nomor 7 Tahun 1989 Tentang Peradilan Agama.

Undang-Undang Nomor 21 Tahun 2008 tentang Perbankan Syariah.

Undang-Undang Nomor 3 tahun 2009 tentang Mahkamah Agung.

Undang-Undang Nomor 49 tahun 2009 tentang Peradilan Umum.

Undang - Undang Nomor 50 Tahun 2009 tentang Perubahan Kedua Atas Undang-

Peraturan Mahkamah Agung Nomor 14 Tahun 2016 tentang Tata Cara Penyelesaian Sengketa Ekonomi Syariah 